\title{
鉄筋挿入接着工法による木質部材接合部の耐熱性向上に関する実験的研究 EXPERIMENTAL STUDY TO IMPROVE THE THERMAL MECHANICAL PROPERTIES OF GLUED-IN ROD JOINTS FOR WOODEN STRUCTURAL MEMBERS
}

\author{
森田武*1, 津畑慎哉*2, 西谷隆之芫, 山野辺宏治*4 \\ Takeshi MORITA, Shinya TSUBATA, Takayuki NISHIYA \\ and Koji YAMANOBE
}

\begin{abstract}
The purpose of this experimental study is to understand and improve the heat resistance of the glued-in rod (GIR) method of joining wooden members. The study investigates the conventional GIR method, in which the inner surface of the reinforcing bar insertion hole is smooth, and an improved GIR method, in which the inner surface of the insertion hole is grooved. Pull-out experiments conducted on specimens show that the improved GIR method offers higher pull-out strength at high temperatures than conventional GIR. Further, after heating and then cooling, the pull-out strength recovers to the unheated room-temperature pull-out strength.
\end{abstract}

Keywords : Wooden structure, Structural joint, Glued-in rod, Glued laminated timber, Heat resistance, Fire resistance 木質構造, 接合部, 鉄筋挿入接着工法, 構造用集成材, 而熱性, 而火性

\section{1. はじめに}

\section{1 鉄筋挿入接着工法およびその耐熱性}

木質構造による大空間を実現するための課題の一つとして, 構造 用集成材を用いたアーチ梁のような木質部材の接合方法があげられ る。その接合方法として, 本検討では GIR 工法 (Glued-in rod : 鉄 筋挿入接着工法）に着目した。GIR 工法は, 接合する木質部材に開 けた先孔に鉄筋等の接合具を挿入し, 接合具との空隙に接着剤を注 入して木質部材同士を接合するものであり, 接着剂の付着力と接合 具を介して応力を伝達する接合方法である。GIR 工法の接着剤とし ては，一般的にエポキシ樹脂系接着剤が使用されている。

エポキシ樹脂は熱硬化性樹脂であり, 耐熱温度は $150 \sim 200^{\circ} \mathrm{C}$ 程

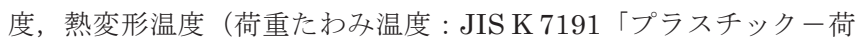
重たわみ温度の試験方法」）は $139 \sim 306^{\circ} \mathrm{C}$ と言われている。また, 接着剂による被着材と被着材の接着は, 被着材の表面の凹凸や孔に 接着剂が入り込んで固化することによる機械的な結合, 被着材と接 着剤の間で双方の分子が接近して強く引き合って生じる分子間力に よる結合, 接着剤の分子と被着材表面の分子の化学反応による結合 などによって生じると言われている。

一方, エポキシ樹脂系接着剂はコンクリートのあと施エアンカー にも用いられている。既往の研究 1),2)では, エポキシ樹脂系注入方式 接着系あと施工アンカーの高温時の付着強度に関する実験結果が報 告されている。これらの研究によれば, 付着強度 (引抜強度) は $50^{\circ} \mathrm{C}$
あるいは $60^{\circ} \mathrm{C}$ 基準とした場合, $70^{\circ} \mathrm{C}$ で $64 \sim 76 \%, 80^{\circ} \mathrm{C}$ で 53 $64 \%, 100^{\circ} \mathrm{C}$ で $21 \sim 29 \%, 140^{\circ} \mathrm{C}$ で $26 \%$ に低下寸ることが示されて いる。これらの研究では被着材がコンクリートと鉄筋であり, 木質 材料とは異なるが, この研究結果から, GIR工法に関しても高温時 に付着強度が低下寸る可能性のあることが示唆される。

さらに，木質材料は高温になるほど，また高含水率であるほど強 度は低下寸ることが報告されている 3)-6)。エポキシ樹脂系接着剤の 付着強度の低下に加えて, 木質材料の強度低下が生じることにより, 高温時の付着強度の低下がさらに顕著となる可能性も考えられる。

\section{2 木質部材と接合部の耐火性}

木質材料は可燃性材料であることから，木質構造の一般的な耐火 設計 7)では，木質部材が火災による高温に曝された場合，その部材 の表面温度は木質材料の引火温度である $260^{\circ} \mathrm{C}$ を超えてはならない ことになっている。大空間建築物において火災が発生した場合, 大 空間の屋根を支えるアーチ梁等の部材に火炎が直接接炎する可能性 は小さく, 火災プルームおよび天井下に蓄積される高温ガス層（煙 層）によって加熱される場合が多く想定される。したがって，大空 間の屋根を支える木質部材が成立するためには，火災プルームおよ び煙層温度が $260^{\circ} \mathrm{C}$ を超えないことが条件となる。

しかし，木質部材の表面温度が $260^{\circ} \mathrm{C}$ を超えないとしても，当該 温度に暴露された木質部材の内部温度も表面温度に伴って上昇する。 そのため, GIR 工法により接合した木質部材の鉄筋挿入位置におけ
*1 清水建設(株)技術研究所 防耐火グループ長・博士（工学）

$* 2$ 清水建設(株)技術研究所 研究員 · 修士 (工学)

$* 3$ 清水建設(侏)設計本部 上席設計長 $\cdot$ 工修

*4 清水建設株技術研究所 上席研究員 · 工博
Group Manager, Institute of Technology, Shimizu Corporation, Dr.Eng. Research Engineer, Institute of Technology, Shimizu Corporation, M.Eng. Chief Design Manager, Design Division, Shimizu Corporation, M.Eng. Chief Research Engineer, Institute of Technology, Shimizu Corporation, Dr.Eng. 
る温度が, 既往の研究 1 , 2)において付着強度の低下が示されている 温度である $70^{\circ} \mathrm{C}$ を超える可能性がある。そのため, エポキシ樹脂系 接着剤を用いた GIR 工法により接合された木質部材の接合部にお ける高温時の耐力低下が懸念されるところであるが, 現状は GIR 工 法の耐熱性に関する検討はほとんどなされていないのが現状である。

\section{3 目的および概要}

本研究は, エポキシ樹脂系接着剤を用いた GIR 工法の耐熱性の把 握と向上を目的とした。本研究では, まず, ある大空間建築物の屋 根を支える木質部材が当該建築物内で想定した火災による加熱を受 けた場合の内部温度を算定し, その結果から GIR 工法の耐熱性の検 討を行う対象温度を設定した。そのうえで, GIR工法により木質材 料に挿入された鉄筋に関して, 設定した対象温度となる高温時およ び冷却後の引抜強度を確認するため, 引抜実験を行った。

なお，本報の内容の一部および構造的な検討に関しては，既報 8)11)において報告している。

\section{2. 火災時に高温に曝される木質部材の内部温度解析 \\ 2. 1 想定条件 \\ （1）木質部材}

本解析で想定した屋根を支持する木質部材の接合部断面および解 析断面を Fig. 1 に示す。想定した部材は断面が(H) $1100 \mathrm{~mm} \times$ (W) $220 \mathrm{~mm}$ の構造用集成材であり, 樹種はカラマツである。GIR 工 法の接合部には軸方向に開けた先孔に鉄筋が挿入され，接着剂が充 填される。

本解析では, 鉄筋は熱容量が大きいこと, 接着剤は近接する木質 部分よりも内側にあるため先孔内表面よりも温度が高くならないこ とを勘案し，鉄筋挿入位置の温度に関して保守的な解析結果を得る ために鉄筋と接着剂は無視し, 木質材料単体で構成される (H) $1100 \mathrm{~mm} \times(\mathrm{W}) 220 \mathrm{~mm}$ の断面を想定した。解析対象の木質部 材は周囲（4 面）から加熱を受けることから，断面の対称性を考慮 して Fig.1 に示すように 1/4 断面をモデル化し, 当該断面を $5 \mathrm{~mm}$ $\times 5 \mathrm{~mm}$ の要素で分割して，2 次元の解析を行うこととした。

(2) 火災温度

本解析で想定した屋根を支持する木質部材が曝される火災温度を
計算結果と併せて Fig. 2 に示す。図の火災温度一時間関係は, 床か ら木質部材下端までの高さを $20.5 \mathrm{~m}$, 可燃物量を $320 \mathrm{MJ} / \mathrm{m}^{2}$ として, 煙層の温度と厚みを考慮したプルーム軸上温度の計算から得られた ものであり,木質部材下端に間欠火炎が到達しないことも確認した。

\section{2 解析方法}

解析には, 一般的な差分法を適用した非定常伝熱解析プログラム 12)-14)を使用した。本プログラムは鋼材やコンクリート等の無機質材 料で構成される部材を対象として作成したものであるが，今回の解 析の火災温度が $260^{\circ} \mathrm{C}$ 以下であることから, 木質部材の炭化や形状・ 寸法の変化は生じないものと仮定して適用した。

解析に用いた熱伝導率および比熱は, 木質材料の密度を $380 \mathrm{~kg} / \mathrm{m}^{3}$ とし，既往の研究 5)15)を参考にして決定した。部材表面と煙層との 間の放射率は 0.9 , 対流熱伝達率は $0.023 \mathrm{~kW} /\left(\mathrm{m}^{2} \cdot \mathrm{K}\right)$ とした。なお, 木質材料の含水率は $10 \%$ とし, $100^{\circ} \mathrm{C}$ で蒸発するものと仮定した。

\section{3 解析結果}

部材内部温度の経時変化を Fig. 2 に示し, 断面内温度分布の経時 変化と最高履歴温度分布を Fig. 3 に示す。これらの図に示すように, 火災温度は約 60 分で最高温度に到達した後，降下に転ずるが，鉄 筋挿入位置は 120 分以降に最高温度に達している。また，鉄筋挿入 位置の温度は部材断面の隅角部（Fig. 1 における E1）で最も高くな り, $70^{\circ} \mathrm{C}$ 程度の温度を履歴する。本解析結果から, エポキシ樹脂系 接着剂を用いた GIR 工法の耐熱性の検討を行う対象温度を, 安全を 見て $80^{\circ} \mathrm{C}$ に設定することとした。

\section{GIR 工法の耐熱性向上に関する考案}

従来の GIR 工法（以下, 従来 GIR と表記）では, Fig. 4(a)に示 すように，木質部材に開けた先孔に鉄筋を挿入してエポキシ樹脂系 接着剤で固定する。しかし，この工法では，集成材一接着剤境界面 の結合は接着剤の接着力に負っており，機械的な結合力はほとんど 期待できないと言える。そこで, 高温時の引抜強度の向上を図るた め, Fig. 4(b)に示すように, 溝加工を施した先孔に鉄筋を挿入して エポキシ樹脂で固定する接着工法（以下，改 GIR と表記）を考案し た。本検討では，改 GIR に関して種々の鉄筋の引抜実験を行うとと もに, 従来 GIR と改 GIR の比較を行った。

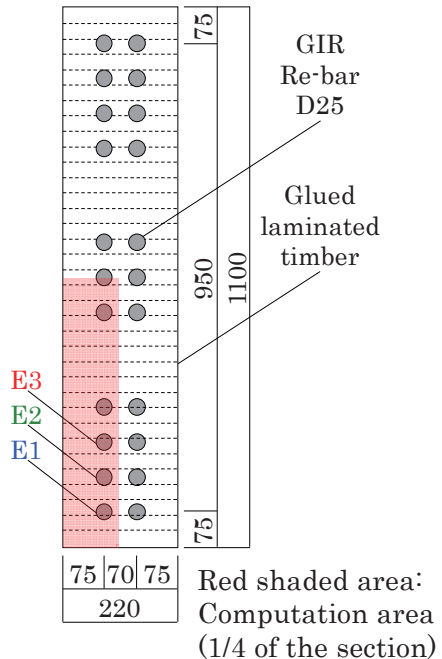

Fig. 1 Calculated cross section of wooden member

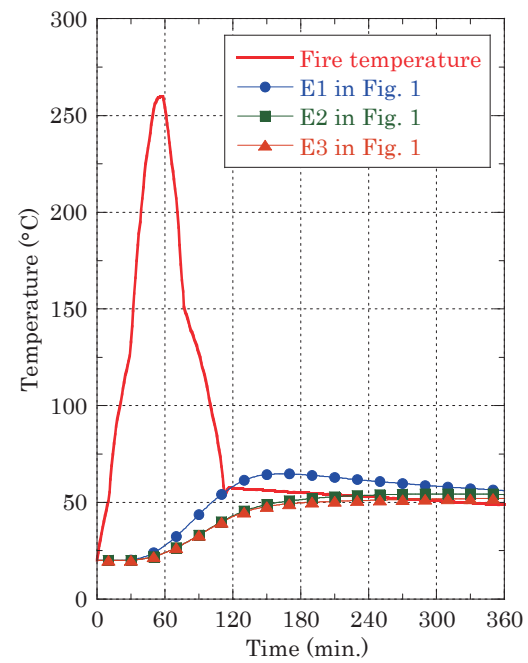

Fig. 2 Temperature-time curve during fire and calculated internal temperature

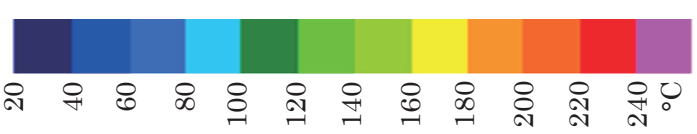

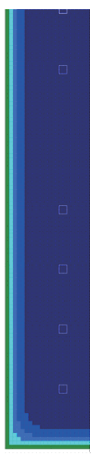

30 min.

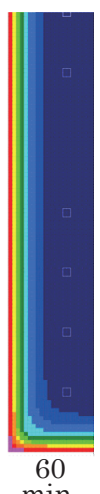

min. min.
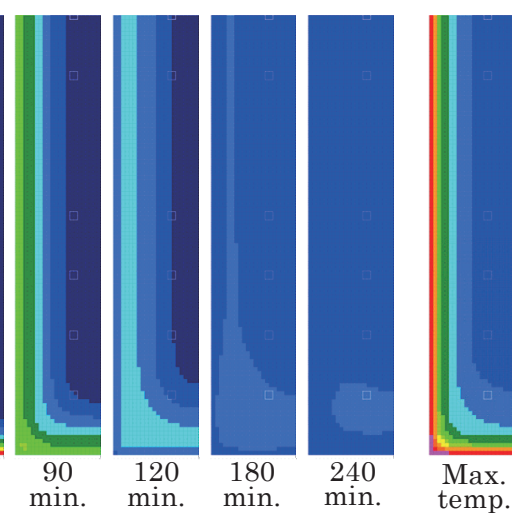

Max.
Fig. 3 Temperature distribution in quarter cross section 


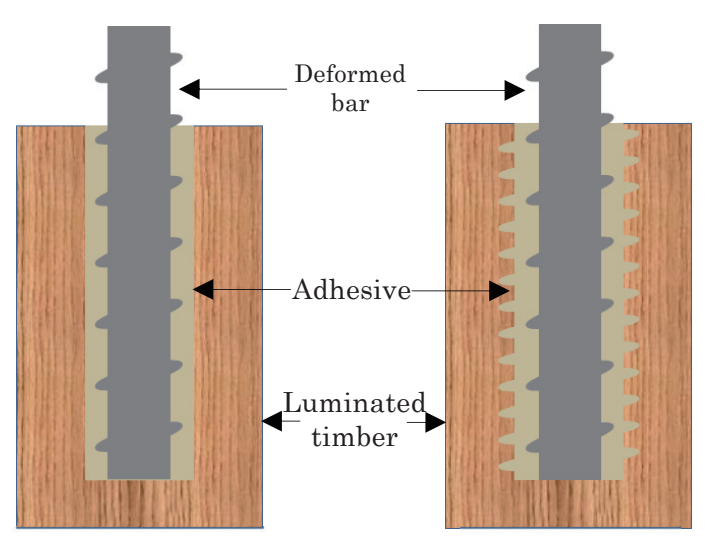

(a) Conventional GIR

(b) Improved GIR

Fig. 4 Schematic diagram of GIR methods

Table 1 Materials used for specimens

\begin{tabular}{|c|c|}
\hline Material & Specifications \\
\hline $\begin{array}{l}\text { Glued } \\
\text { laminated } \\
\text { timber }\end{array}$ & $\begin{array}{l}\text { Wood product: Glued laminated timber } \\
\text { composed of different grade laminar } \\
\text { (symmetrical composition) } \\
\text { Strength grade: E105-F300 } \\
\text { Tree species: Larch } \\
\text { Shape/Dimensions : Cylinder/Diameter: } \\
\text { 150mm; Height: } 300 \mathrm{~mm} \\
\text { Moisture content*1: } 9-14 \% \\
\text { Prepared hole for inserting re-bar: } \\
\text { [Conventional GIR] Inner diameter: } 32 \mathrm{~mm} \text {; } \\
\text { Depth: } 250 \mathrm{~mm} \\
\text { [Improved GIR] Grooving after drilling } \\
\text { pilot hole } \\
\text {-Pilot hole: Inner diameter } 32 \mathrm{~mm} \text {; depth } \\
\text { 250mm } \\
\text {-Groove: Cut with a } 36 \mathrm{~mm} \text { lag screw bolt }\end{array}$ \\
\hline $\begin{array}{l}\text { Reinforcing } \\
\text { bar }\end{array}$ & $\begin{array}{l}\text { Type/Grade: Deformed bar D25 / SD345 (JIS } \\
\text { G } 3112 \text { ) } \\
\text { Length: } 1,250 \mathrm{~mm} \\
\text { Threaded M22 at end opposite to the } \\
\text { adhesive joint } \\
\text { Threaded length: } 300 \mathrm{~mm} \\
\text { Yield strength: } 367-375 \mathrm{~N} / \mathrm{mm}^{2} \\
\text { Tensile strength: } 556-572 \mathrm{~N} / \mathrm{mm}^{2} \\
\end{array}$ \\
\hline Adhesive & $\begin{array}{l}\text { Type: Heat-resistant two-component reaction- } \\
\text { curable epoxy resin adhesive }\end{array}$ \\
\hline
\end{tabular}

*1: Moisture contents measured at specimen surface using a wood moisture tester (MT-700, Kett Electric Laboratory) just before the experiment.

\section{4. 実験概要}

\section{1 試験体}

（1）使用材料

試験体に使用した材料を Table 1 に示す。試験体木部には，異等 級構成集成材 (対称構成) で強度等級 E105-F300 のカラマツの構造 用集成材を使用した。挿入鉄筋には, JIS G 3112 の異形棒鋼 (D25,

SD345）を使用した。当該棒鋼 3 本の力学特性の実測值は, 降伏点 が 367〜 375N/mm²であり, 引張強度が 556〜 572N/mm゙あった。 接着剤には, 通常のエポキシ樹脂系接着剤よりも耐熱温度を高めた 耐熱性 2 液反応硬化型エポキシ樹脂系接着剤を使用した。

（2）試験体の形状・法

試験体の形状・寸法を Fig. 5 に示す。試験体は，(D) $150 \mathrm{~mm} \times$ (H) $300 \mathrm{~mm}$ の円柱形をした木部に長さ $1250 \mathrm{~mm}$ の鉄筋を挿入し, 木部と鉄筋を接着剤で接着したものである。円柱形の木部に関して

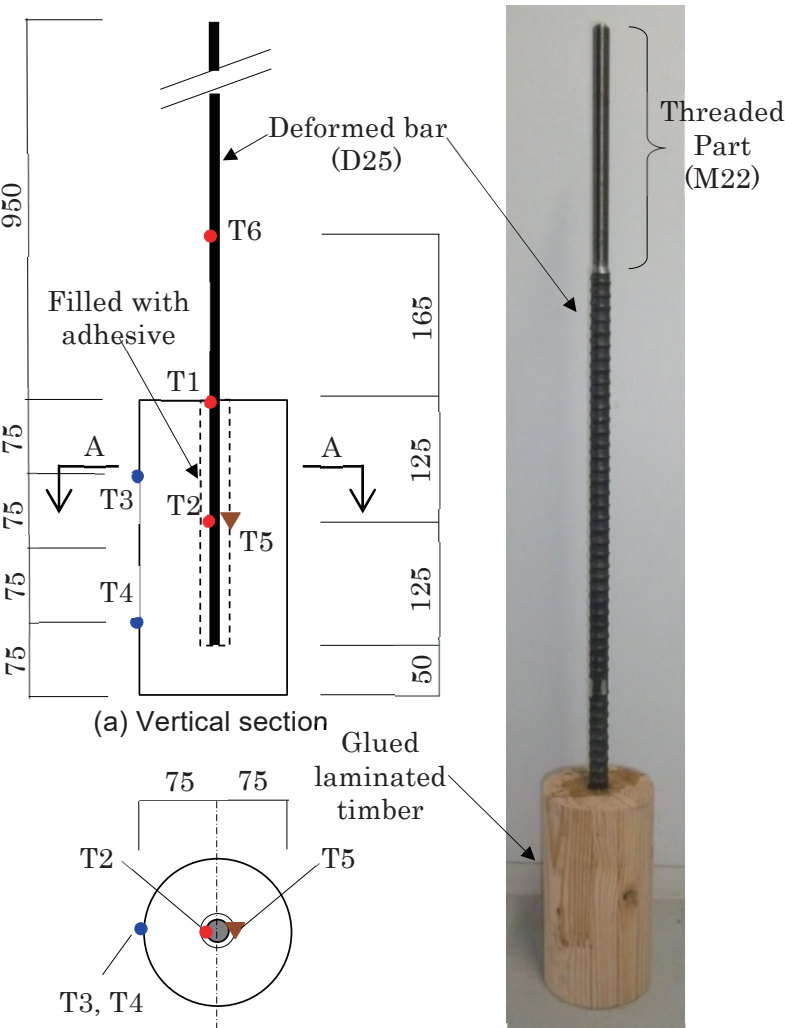

(b) A-A section

(c) Photo of specimen

T1, T2, T6: Thermocouples on the reinforcing bar

T3, T4: Thermocouples on the surface of glued laminated timber (for controlling furnace temperature)

T5: Thermocouple at the boundary between glued laminated timber and adhesive

Fig. 5 Shape, dimensions and temperature measurement points of specimen

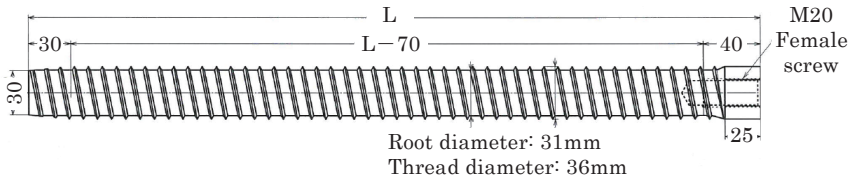

Fig. 6 Lag screw bolt used for grooving
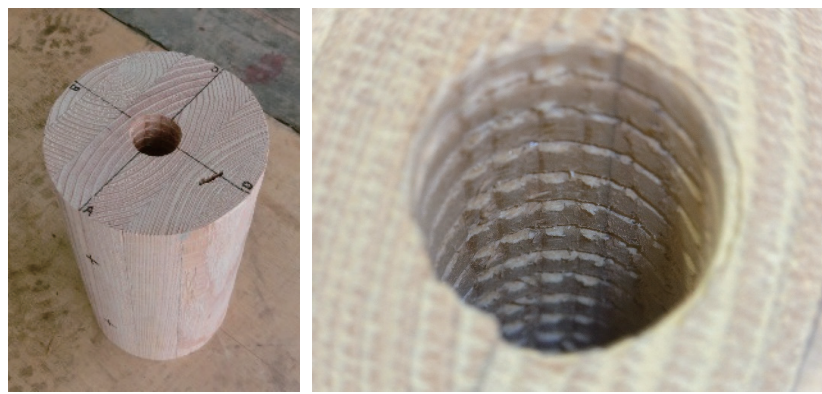

Photo 1 Prepared hole with groove for improved GIR

は，鉄筋を挿入するための先孔を加工した。従来 GIR の先孔は，内 表面に凹凸のない通常の孔で，内径 $32 \mathrm{~mm}$ ・深さ $250 \mathrm{~mm}$ とした。 改 GIR の先孔は, 内径 $32 \mathrm{~mm}$ ・深さ $250 \mathrm{~mm}$ の下孔を開けた後, こ の下孔に対して Fig. 6 に示すネジ径 $36 \mathrm{~mm}$ ・谷径 $31 \mathrm{~mm}$ のラグス クリューボルトをねじ込んで抜き出すことにより溝加工を施した。 溝加工を施した改 GIR の先孔を Photo 1 に示す。

なお，実用に供している GIR 工法における先孔の深さ（鉄筋の埋 
込み長さ）は, 鉄筋径 D19 または D25 に関して, 集成材のヤング 係数区分が $\mathrm{E} 105$ 以上, かつ鉄筋の捜入方向が集成材の繊維方向と 同じ場合, $300 \mathrm{~mm}$ 以上とされている。しかし, 本実験では, 高さ $350 \mathrm{~mm}$ の電気炉で試験体木部が均一に加熱されるように木部高さ を $300 \mathrm{~mm}$ としたこと, および接着剤を充填するために先孔を貫通 させないこととしたことから, 深さ $300 \mathrm{~mm}$ 以上の先孔を設けるこ とができなかった。そのため, 本実験では, 先孔の深さを鉄筋径の 10 倍と定めて $250 \mathrm{~mm}$ とした。

(3) 試験体温度の測定位置

試験体温度は，Fig. 5 に示すように，鉄筋温度（T1，T2，T6）, 木部表面温度 ( T3, T4), 木部先孔内表面と充填接着剂の境界温度 （T5）（以下，境界温度と言う）の合計 6 箇所に取り付けた素線径 $0.65 \mathrm{~mm}$ の $\mathrm{K}$ 熱電対で測定した。木部表面温度は $\mathrm{T} 3, \mathrm{~T} 4$ の位置に, Photo 2 に示すように, 熱電対を木部上下に 2 本ずつ取り付け, 各 位置の 1 本ずつを電気炉の温度制御と測定温度の記録に使用した。

（4）木部と鉄筋の接着

試験体製作における木部と鉄筋の接着・養生，および引抜実験の 一連の作業は, 室温が外気温とほぼ同等な実験室内で行った。試験 体木部の先孔の容積から鉄筋の体積を差し引いた量より若干多めの 接着剂を先孔に充填した後, ただちに, 鉄筋芯が先孔の中心と一致 するように鉄筋を挿入し，接着剤が硬化するまで鉄筋を鉛直に保持 した。接着作業後, 従来 GIR では平均気温約 $10^{\circ} \mathrm{C}$ 環境下で 12 日 間（3 月下旬〜 4 月上旬), 改 GIR では平均気温約 $20^{\circ} \mathrm{C}$ の環境下で 7 日間（5月中旬〜下旬）養生した後，順次引抜実験を実施した。

なお，すべての試験体の引抜実験を完了するのに要した期間は, 従来 GIR において約 1 か月間（4月上旬～ 5 月中旬), 改 GIR にお いても約 1 か月間（5月中旬から 6 月中旬）であった。

\section{2 実験装置}

実験装置を Fig. 7 に示す。実験装置は, 鉄筋を引き抜くための載 荷装置と試験体木部を加熱するための電気炉で構成される。加力装 置には $350 \mathrm{kN}$ センターホールジャッキと $500 \mathrm{kN}$ ロードセルを使用 した。試験体木部の上面には, Fig. 7(c)に示すように, 均等に引抜 荷重が作用するように, 中心部に直径 $40 \mathrm{~mm}$ の孔を設けた支圧板を 設置した。また，鉄筋の引抜変位を測定するための治具を鉄筋に取 り付けた。電気炉の内部を Fig. 7(d)に示す。炉内寸法は(D) $200 \mathrm{~mm}$ × (H) $350 \mathrm{~mm}$ である。電気炉上下端の隙間からの放熱を防ぐため, 無機質繊維系ブランケットで電気炉の上下面を断熱養生した。

\section{3 実験内容および条件}

実験は，試験体を加熱する際の加熱温度（試験体表面温度）－時 間関係を決めるための検討, および引抜実験（I～IV）の二つに大き く分けられる。引抜実験の条件と試験体数を Table 2 および Fig. 8 に示す。

（1）引抜実験のための加熱温度一時間関係の検討

試験体の鉄筋挿入部の温度（境界温度 : Fig. 5 における T5）が, 2 章の解析的検討により決定した対象温度である $80^{\circ} \mathrm{C}$ になるう に, 電気炉内に設置した試験体に対する加熱条件を決める必要があ った。そのため, 解析と実験の双方により電気炉内における加熱温 度一時間関係を検討した。

（2）常温引抜実験（実験 I）

鉄筋に引抜力 (加力速度 : $0.4 \mathrm{kN} / \mathrm{sec}, \mathrm{II}, \mathrm{III}$ および IV の引抜実
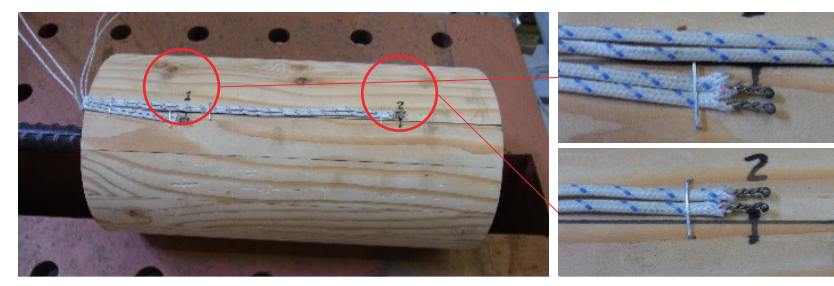

Photo 2 Thermocouples for measuring surface temperature

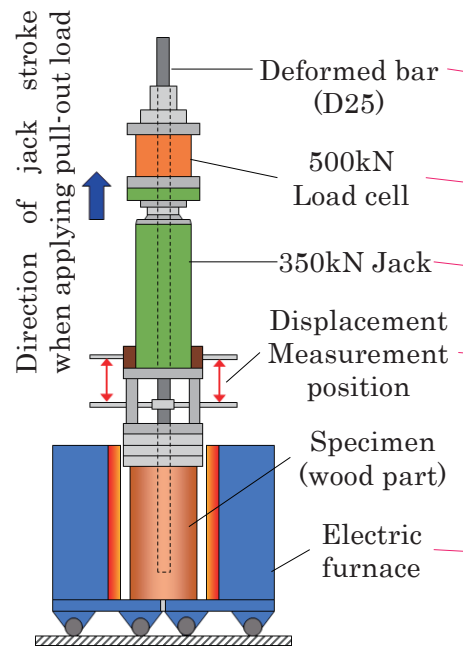

(a) Schematic diagram of experimental equipment

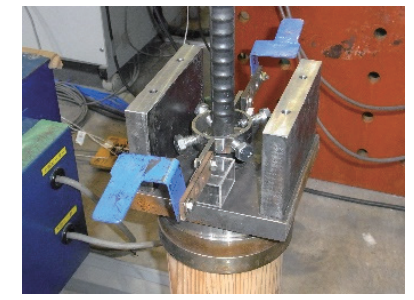

(c) Support plate and displacement measurement jig

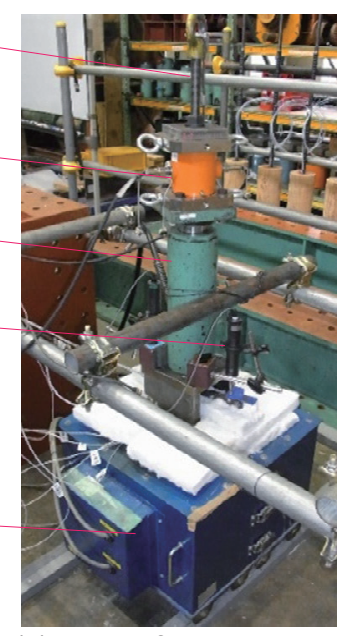

(b) Photo of experimental equipment

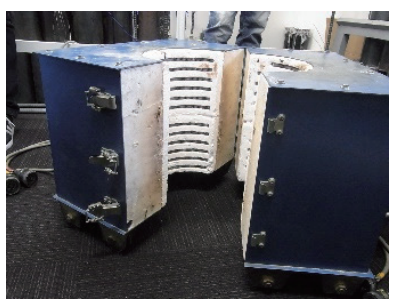

(d) Inside of electric furnace
Fig. 7 Experimental setup

Table 2 Experimental conditions and number of specimens for Pull-out experiments

\begin{tabular}{|c|c|c|c|c|}
\cline { 2 - 5 } \multicolumn{1}{c|}{} & Expt. I & Expt. II & Expt. III & Expt. IV \\
\hline $\begin{array}{c}\text { Conventional } \\
\text { GIR }\end{array}$ & 2 & 2 & $4\left(\mathrm{NL}^{* 1}\right)$ & $2\left(\mathrm{NL}^{* 3}\right)$ \\
\hline $\begin{array}{c}\text { Improved } \\
\text { GIR }\end{array}$ & 3 & 4 & $\begin{array}{c}6\left(\mathrm{NL}^{* 1}\right) \\
6\left(\mathrm{~L}^{*}\right)\end{array}$ & $5\left(\mathrm{~L}^{* 4}\right)$ \\
\hline
\end{tabular}

*1: Specimen not loaded during heating

*2: Constant load applied to specimen during heating

*3: Specimen not loaded during heating and cooling

*4: Constant load applied to specimen during heating and cooling

験も同じ載荷速度を適用）を与えて最大荷重を確認するまで加力を 継続し，常温時の引抜強度を確認した。

加力速度については, GIR 工法の引抜試験に関する規格や規準が ないことから，既往の研究や基準を参考にした。既往の研究 16)-21)に よれば, 載荷速度は, 荷重制御で $0.25 \sim 0.30 \mathrm{kN} / \mathrm{sec}$, 変位制御で 0.2

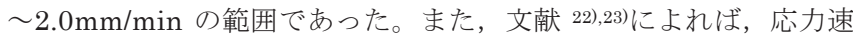
度が毎分 $49 \mathrm{~N} / \mathrm{mm}^{2}$ 以下または $50 \mathrm{~N} / \mathrm{mm}^{2}$ 以下となるように規定さ れており，これに基づくと今回の試験体の場合は約 $0.42 \mathrm{kN} / \mathrm{sec} に$ なる。以上の文献調査結果を参考にして, 本実験では載荷速度を 

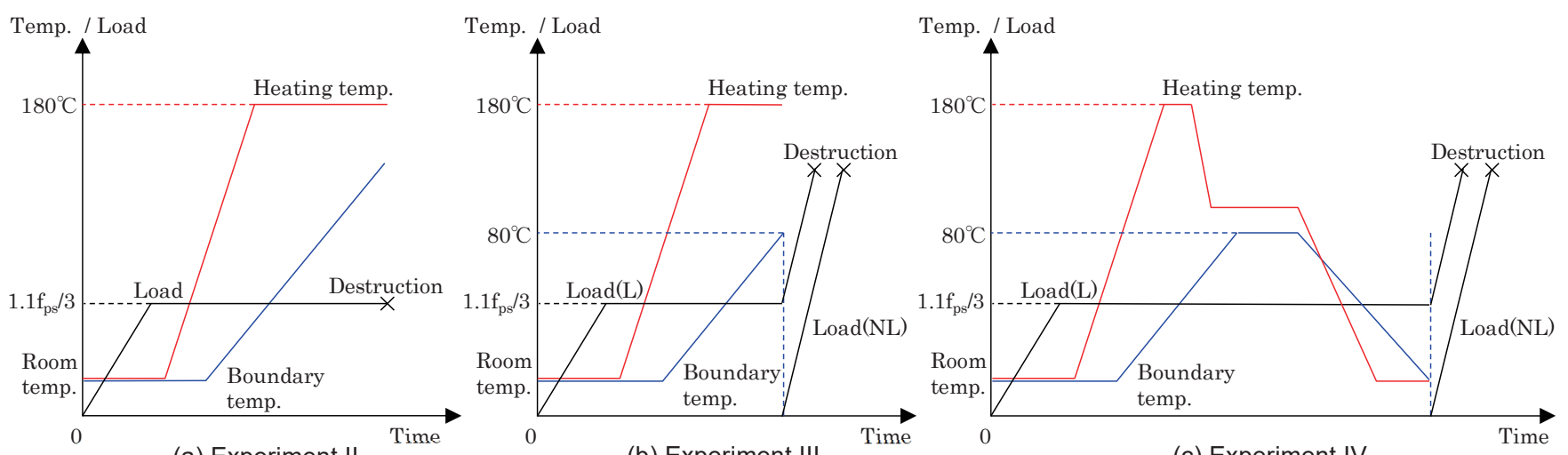

[Note] $\mathrm{f}_{\mathrm{ps}}$ indicates the pull-out strength at room temperature.

Fig. 8 Schematic diagram of the relationship between temperature/load and time in pull-out experiments

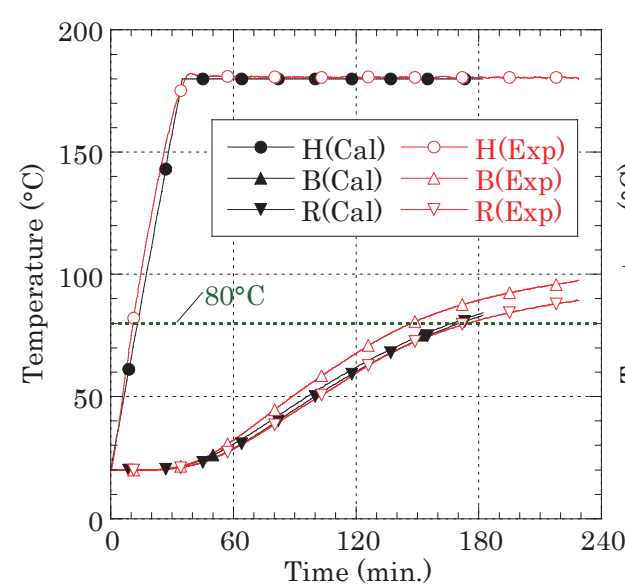

[Note] H: Heating; B: Boundary; R: Re-bar; Cal: Calculation; Exp: Experiment

Fig. 9 Temperature-time relationship in experiments II and III

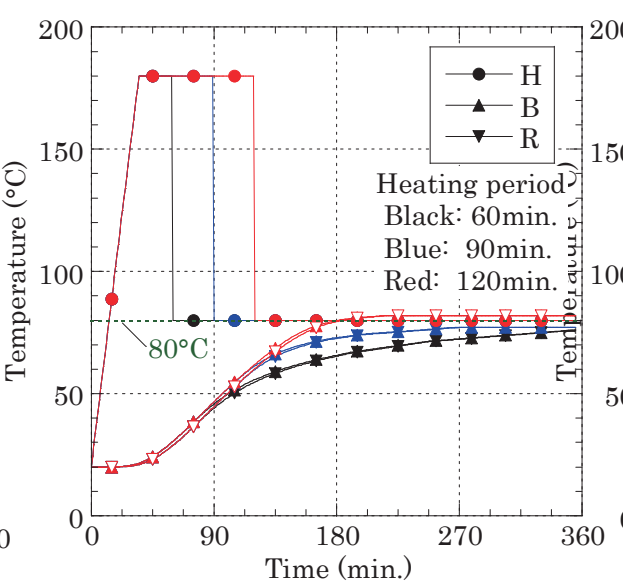

(a) Calculation

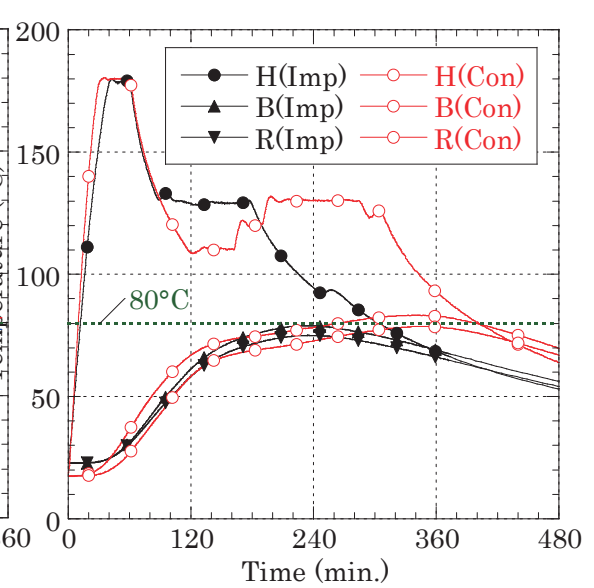

(b) Experiment

[Note] H: Heating; B: Boundary; R: Re-bar;

Imp: Improved GIR; Con: Conventional GIR

Fig. 10 Temperature-time relationship in experiment IV

$0.4 \mathrm{kN} / \mathrm{sec}$ とした。なお，この載荷速度であれば，試験体の木部に 作用する圧縮載荷速度は文献 ${ }^{24)}$ の值を超えないことも確認した。

（3）一定荷重昇温引抜実験（実験 II）

加熱・加力条件の模式図を Fig. 8(a)に示す。常温引抜実験結果か ら得られた引抜強度の $1.1 / 3$ 倍の引抜荷重を載荷して一定に保持し た状態で, 鉄筋が引抜けるまで加熱を継続し, 鉄筋引抜時の境界温 度を確認した。

なお，加熱中一定に保持した引抜荷重は，GIR 工法には一般的な 耐力の設計式がないため, 曲げ降伏型接合具を用いた接合方法の設 計式 25)を参考にして定めた。すなわち, 常温時の実験では降伏の判 断が難しかったため, 終局耐力（本実験における常温時引抜強度） に基準化係数 (1/2) と安全係数 (2/3) を乗じた值を基準許容耐力と し，これに長期荷重を想定して荷重継続期間影響係数（長期：1.1） を乗じた值を加熱中一定に保持する引抜荷重とした。

(4) 高温引抜実験（実験 III）

加熱・加力条件の模式図を Fig. 8(b)に示す。本実験では, 加熱中 の載荷条件として, 無載荷 $(\mathrm{NL})$ と載荷 $(\mathrm{N})$ の 2 種類を設定した。 無載荷加熱では加熱中に引抜力を作用させず, 載荷加熱では加熱中 に常温時引抜強度の $1.1 / 3$ 倍の引抜荷重を作用させた。1.1/3 倍の根 拠は本節(3)に述べたとおりである。これらの条件で試験体を加熱し，

境界温度が $80^{\circ} \mathrm{C}$ になった時点で速やかに, 鉄筋に引抜力を与えて最 大荷重を確認するまで加力を継続した。

（5）加熱・冷却後引抜実験（実験 IV）

加熱・加力条件の模式図を Fig. 8(c)に示す。本実験では, 従来 GIR は無載荷 $(\mathrm{NL})$, 改 GIR では載荷（L）の条件で試験体を加熱・冷 却した。境界温度が $80^{\circ} \mathrm{C}$ になった時点から当該温度を $2 \sim 3$ 時間程 度保持したの後，常温まで自然放冷してから，鉄筋に引抜力を与え て最大荷重を確認するまで加力を継続した。実験条件を載荷（L) と した改 GIR では，加熱・泠却期間中，常温時引抜強度の 1.1/3 倍の 引抜荷重を載荷して一定に保持した。

\section{5. 引抜実験のための加熱温度一時間関係の検討 \\ 5.1 最高温度と昇温速度}

(1) 加熱条件の設定

これまでに実施した種々の木質部材の耐火実験の結果 26)を踏ま え, 試験体の木部の加熱による燃焼や炭化が生じない温度として, 加熱温度 (T3, T4により測定される試験体表面温度)を最高で $180^{\circ} \mathrm{C}$ に設定することとした。また，Fig. 2 に示した火災温度一時間関係 では加熱開始後約 35 分の時点に加熱温度が $180^{\circ} \mathrm{C}$ に達することか ら, 引抜実験の昇温速度もこれに合わせて, 約 35 分で加熱温度が 
$180^{\circ} \mathrm{C}$ に到達するようにした。 $180^{\circ} \mathrm{C}$ に達した後は, 境界温度が所定 の温度になるように当該温度を一定に保持寸ることとした。

（2）加熱実験および解析による確認

（1）で設定した加熱条件により試験体を加熱した場合の内部温度 の経時変化を, 非定常伝熱解析および加熱実験によって確認した。 解析は 2 章と同じ方法を適用した。解析結果と加熱実験結果を併せ て Fig. 9 に示す。解析および実験から, 加熱開始後 150〜170 分程 度で境界温度が $80^{\circ} \mathrm{C}$ に達すること, 鉄筋温度は境界温度よりも5〜 $10^{\circ} \mathrm{C}$ 程度低くなることが確認された。

\section{2 境界温度一定保持・冷却条件}

加熱・冷却後引抜実験において境界温度を $80^{\circ} \mathrm{C} て ゙ 一$ 定に保持する 条件を決めるため, 伝熱解析によって電気炉内の温度の制御の目安 を検討した。解析では, 加熱温度が加熱開始から 35 分で $180^{\circ} \mathrm{C}$ に達 した後, $180^{\circ} \mathrm{C}$ 保持時間を $25,55,85$ 分とし, その後 $80^{\circ} \mathrm{C}$ 一定の 履歴を仮定した。解析結果を Fig. 10(a)に示寸。解析から, $180^{\circ} \mathrm{C} の$ 保持時間を 120 分とすると $80^{\circ} \mathrm{C}$ を超え， $60 \sim 90$ 分程度にすると境 界温度が $80^{\circ} \mathrm{C}$ 程度に保たれる目安が得られた。

実際の加熱温度の制御例を Fig. 10(b)に示す。図に示すように炉 内温度を $180^{\circ} \mathrm{C}$ から $80^{\circ} \mathrm{C}$ に急激に降温させることは難しい。Fig 10(b)に示した従来 GIR では, $80^{\circ} \mathrm{C}$ に向けて自然放冷によって炉内 を冷却したが, その過程で境界温度の上昇勾配が低下した。そのた め, 改 GIR では $180^{\circ} \mathrm{C}$ と $80^{\circ} \mathrm{C}$ の間温度である $130^{\circ} \mathrm{C}$ 目安に加 熱温度を降下させ, $130^{\circ} \mathrm{C}$ 到達後, $130^{\circ} \mathrm{C}$ の継続時間を手動で制御し て, 境界温度が $2 \sim 3$ 時間程度, 約 $80^{\circ} \mathrm{C}$ を保持するようにした。試 験体の冷却は, 加熱停止後, 電気炉内で自然放冷とした。

\section{6. 引抜実験の結果および考察}

\section{1 実験結果概要（改 GIR と従来 GIR の比較）}

Table 3 に実験結果一覧を示す。表には複数の試験において測定 された温度と荷重の範囲（最大值と最小值）を示した。また，試験 体数は少ないが，母集団が正規分布になるものと仮定して，95\%信 頼区間の下限值となる最大引抜力（以下，引抜強度と言う）と付着 強度を示した。常温引抜実験と加熱・冷却後引抜実験の破壊モード は，集成材が鉄筋に沿って割れる付着割裂破壊（以下，割裂破壞と 表記）であった。一方，一定荷重昇温引抜実験と高温引抜実験の破 壊モードは，集成材に割裂は生じず，先孔内面と接着剤の界面のす べりによる付着破壊（以下，す心゙り破壊と表記）であった。

（1）常温引抜実験（実験 I)

改 GIR の引抜強度は従来 GIR よりも低く, 改 GIR の引抜強度は 従来 GIR の 90\%程度となった。このような結果になった原因とし て, 試験体木部の集成材に関して, 従来 GIR と改 GIR の製作時期 が異なっていたこと，製作時にラミナの強度区分やその配置を厳密 に管理していなかったことなどの可能性が考えられる。なお，別途 行った実験 10)では, 従来 GIR よりも改 GIR の方が引抜強度は高く なる結果が得られている。

（2）一定荷重昇温引抜実験（実験 II）

一定荷重を常温引抜実験の引抜強度の $1.1 / 3$ としたため, 改 GIR の昇温時の一定荷重が従来 GIR よりも小さいことが影響している 可能性もあり，本実験結果から従来 GIR に対する改 GIR の優位性 を結論づけることは難しいが, 破壊時温度の平均值は, 改 GIR が $96^{\circ} \mathrm{C}$, 従来 GIR が $61^{\circ} \mathrm{C}$ であり, 改 GIR の方が約 $40^{\circ} \mathrm{C}$ 高くなった。

Table 3 Pull-out experiment results

\begin{tabular}{|c|c|c|c|c|c|c|c|c|c|c|c|}
\hline \multirow[t]{2}{*}{ GIR } & \multirow[t]{2}{*}{$\begin{array}{l}\text { Expt. } \\
\text { series }\end{array}$} & \multirow[t]{2}{*}{$\begin{array}{c}\text { Load } \\
\text { during } \\
\text { heating } \\
\text { and/or } \\
\text { cooling } \\
(\mathrm{kN})\end{array}$} & \multicolumn{2}{|c|}{$\begin{array}{l}\text { Temperature of } \\
\text { surface } \\
\left({ }^{\circ} \mathrm{C}\right) \\
{ }^{*} 1\end{array}$} & \multicolumn{2}{|c|}{$\begin{array}{c}\text { Temperature } \\
\text { of re-bar } \\
\left({ }^{\circ} \mathrm{C}\right) \\
{ }^{*} 1\end{array}$} & \multirow{2}{*}{$\begin{array}{c}\text { Boundary } \\
\text { temperature } \\
\text { between } \\
\text { wood and } \\
\text { adhesive } \\
\left({ }^{\circ} \mathrm{C}\right) \\
{ }^{*} 1\end{array}$} & \multicolumn{3}{|c|}{$\begin{array}{c}\text { [Upper row] } \\
\text { Maximum pull-out load }(\mathrm{kN}) \\
\text { or } \\
\text { Failure temp. for experiment II } \\
\underline{\left({ }^{\circ} \mathrm{C}\right)} \\
{[\text { Lower row }]} \\
\text { Bond strength }\left(\mathrm{N} / \mathrm{mm}^{2}\right) \\
\end{array}$} & \multirow[t]{2}{*}{$\begin{array}{c}\text { Failure } \\
\text { mode } \\
* 2\end{array}$} \\
\hline & & & $\mathrm{T} 3$ & $\mathrm{~T} 4$ & $\mathrm{~T} 1$ & $\mathrm{~T} 2$ & & Measured & $\begin{array}{c}\text { Avg. } \\
(\mu)\end{array}$ & $\begin{array}{c}\mu-1.96 \sigma \\
* 3\end{array}$ & \\
\hline \multirow{6}{*}{ Conventional } & I & 0 & & & & & & $\frac{137.5-143.0}{7.00-7.28}$ & $\begin{array}{c}140.3 \\
6.96\end{array}$ & $\begin{array}{c}137.0 \\
6.80\end{array}$ & Split \\
\hline & II & 52.0 & 181 & $175-177$ & $39-40$ & $42-44$ & $55-66$ & $55-66$ & 61 & 0.00 & Slip \\
\hline & \multirow{2}{*}{ III(NL) } & \multirow[t]{2}{*}{0} & \multirow{2}{*}{$175-181$} & \multirow{2}{*}{ 166-182 } & \multirow{2}{*}{$46-55$} & \multirow{2}{*}{$55-69$} & \multirow{2}{*}{$81-83$} & $38.2-65.0$ & $4 \overline{49.0}$ & 38.5 & \multirow{2}{*}{ Slip } \\
\hline & & & & & & & & $1.95-3.31$ & 2.49 & 1.96 & \\
\hline & \multirow{2}{*}{$\mathrm{IV}(\mathrm{NL})$} & 0 & 179-181 & 180-183 & $55-62$ & 71-79 & $82-83$ & $134.3^{-143.3}$ & 138.8 & 133.6 & \multirow{2}{*}{ Split } \\
\hline & & 0 & 17-21 & 17-21 & $16-20$ & 17-21 & $17-22$ & 6.84-7.30 & 7.07 & 6.80 & \\
\hline \multirow{7}{*}{ Improved } & I & 0 & & & & & & $\begin{array}{c}120.4-127.7 \\
6.13-6.50\end{array}$ & $\begin{array}{c}123.8 \\
6.30\end{array}$ & $\begin{array}{c}120.3 \\
6.13\end{array}$ & Split \\
\hline & II & 45.4 & 180-181 & $180-183$ & $55-82$ & 71-97 & $79-108$ & 79-108 & $\underline{96}$ & 0 & Slip \\
\hline & III(NL) & 0 & 169-177 & $167-173$ & 60-72 & 66-77 & $82-83$ & $\begin{array}{c}85.3-114.9 \\
434-5.85\end{array}$ & $\begin{array}{l}97.7 \\
4.98\end{array}$ & $\begin{array}{l}87.5 \\
4.61\end{array}$ & Slip \\
\hline & \multirow{2}{*}{$\operatorname{III}(\mathrm{L})$} & \multirow[b]{2}{*}{45.4} & & & & & & $\begin{array}{l}4.040 .00 \\
55.5-88.8\end{array}$ & $\frac{4.50}{74.5}$ & $\begin{array}{l}4.01 \\
61.6\end{array}$ & \\
\hline & & & 177-180 & $173-181$ & $52-66$ & $61-75$ & $81-82$ & $2.83-4.52$ & 3.79 & 3.31 & Slip \\
\hline & IV(L) & 45.4 & 181-183 & 176-187 & $62-65$ & $75-77$ & $81-86$ & $157.8-168.4$ & 162.8 & 158.2 & Solit \\
\hline & IV(L) & 45.4 & $23-27$ & $23-26$ & $22-26$ & $23-27$ & $23-27$ & $8.03-8.58$ & 8.33 & 8.10 & Spplit \\
\hline
\end{tabular}

*1 For experiment I, the temperature at failure is shown.

For experiments III(NL) and III(L), the temperature at maximum load is shown.

For experiments IV(NL) and IV(L), the upper row shows the maximum historical temperature and the lower row shows the temperature at maximum load.

*2 Split: indicates failure due to splitting of wood.

Slip: indicates slip failure at the interface between inner surface of the insertion hole and the adhesive.

*3 $\mu$ : Sample mean; $\sigma$ : Sample standard deviation; $\mu-1.96 \sigma$ : Lower limit of $95 \%$ confidence interval 
（3）高温引抜実験（実験 III）

引抜強度の平均值は, 改 GIR が無載荷加熱で $97.7 \mathrm{kN}$, 載荷加熱 で $74.5 \mathrm{kN}$ であったのに対し, 従来 GIR は無載荷加熱で $49 \mathrm{kN}$ であ った。従来 GIR の無載荷加熱時の引抜強度に対して, 改 GIR の引 抜強度は, 無載荷加熱で約 2 倍, 載荷加熱で約 1.5 倍高くなった。 改 GIR の高温引抜強度は従来 GIRよりも明らかに改善されている と言える。

\section{（4）加熱 - 冷却後引抜実験（実験 IV）}

引抜強度の平均值は, 従来 GIR が $162.8 \mathrm{kN}$, 従来 GIR が $138.8 \mathrm{kN}$ であり改 GIR の方が $24 \mathrm{kN}$ 高くなった。従来 GIR は一定荷重状態 で加熱すると鉄筋が引抜けてしまうことから無載荷加熱で行った。 これに対して改 GIR では載荷状態での加熱・冷却であった。そのた め, 実験は改 GIR の方が厳しい条件であったにもかかわらず，引抜 強度が従来 GIR よりも高かったことから, 加熱冷却後の引抜強度 は，従来 GIRよりも改 GIR の方が改善されていると言える。

\section{2 常温引抜実験（実験 I)}

Fig. 11 に荷重一変位関係および引抜実験後の試験体木部の割裂 状況を示す。従来 GIR ではパラボラ型の曲線であったが，改 GIR では初期の勾配が緩やかな $\mathrm{S}$ 字型の曲線になった。一方, 別途行っ た引抜実験 10)では, 従来 GIR, 改 GIR ともにパラボラ型の荷重一 変位関係になった。荷重一変位関係については, 実験装置や試験体 の形状なども影響すると考えられることから，さらなる検討とデー タの蓄積が必要であると言える。

\section{3 一定荷重昇温引抜実験（実験 II)}

Fig. 12 に変位一温度関係, 温度一時間関係および引抜実験後の試 験体の状況を示す。Fig. 12(a)に示すように，従来 GIR では，55〜 $66^{\circ} \mathrm{C}$ に達すると鉄筋の引抜変位が急増する挙動を示した。これに対 して, 従来 GIR とは異なり, 改 GIR では勒性的な挙動を示した。 改 GIR では, 図中の I2 では明確でないが, 55〜 $75^{\circ} \mathrm{C} て ゙$ 変位が緩や かに増加を始めるが, その後, 変位速度が遅くなる温度域があり, 最終的に $95 \sim 108^{\circ} \mathrm{C}$ で抜変位が急増して破壊に至った。また, 改 GIR も従来 GIR も破壊モードはすべり破壊であった。従来 GIR は 先孔内面と接着剤の境界面が滑らかで機械的な結合がなされていな いが, 改 GIR では, Fig. 4 に示したように, 先孔内面の溝に接着剤
が入り込んで固化することによる機械的な結合がなされている。 Fig.12(c)に示すように, 先孔の内表面の木部を削りとったような微 小な木片が鉄筋の周囲の接着剤表面に付着している。このことから 加熱中の一定荷重の大きさに違いがあるものの，接着剤と木部との 機械的な結合が寄与して，改 GIR の破壊温度が従来 GIR よりも高 くなった可能性が考えられる。

\section{4 高温引抜実験（無載荷加熱, 載荷加熱）（実験 III）}

（1）無載荷加熱（改 GIR，従来 GIR）

Fig. 13 に無載荷加熱の場合の荷重一変位関係および引抜実験後 の試験体内部の状況を示す。試験体内部の状況は，木部を切断して 観察した。Fig. 13(a)に示すように，無載荷加熱の改 GIR では，常 温時と同様に，若干 $\mathrm{S}$ 字型の曲線形状を呈した。Fig. 13(b)に示すよ うに, 従来 GIR では先孔内面と接着剤表面が滑らかな状態のまます 心゙って鉄筋が引抜けている。これに対して, 改 GIR では鉄筋と一体 化した接着層が先孔の溝を破壊しながら鉄筋が引抜けたことを示し ている。一定荷重昇温引抜実験の場合と同様に，先孔内面の溝に接 着剂が入り込んで固化することによる機械的な結合が寄与し, 改 GIR の高温引抜強度が従来 GIR よりも高くなったと考えられる。
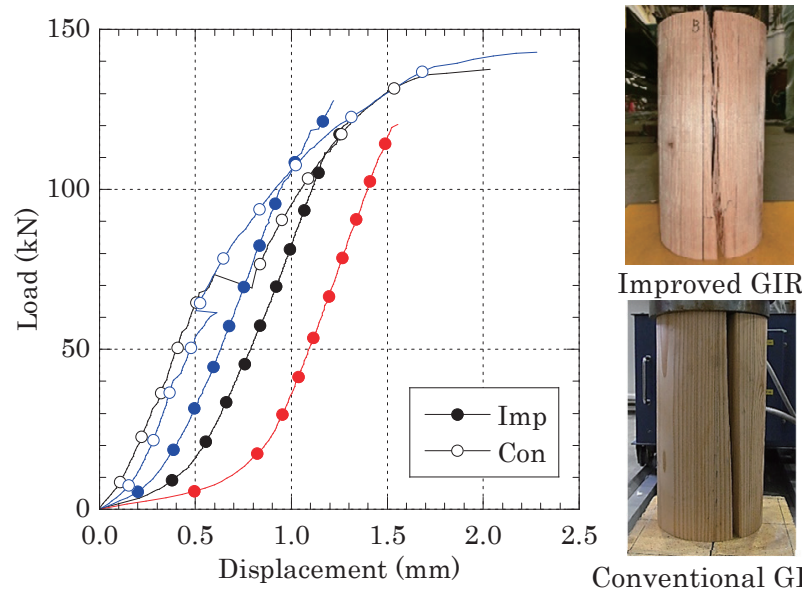

Note Imp: Improved GIR; Con: Conventional GIR

Fig. 11 Load-displacement relationship measured in experiment I and specimens after the experiment

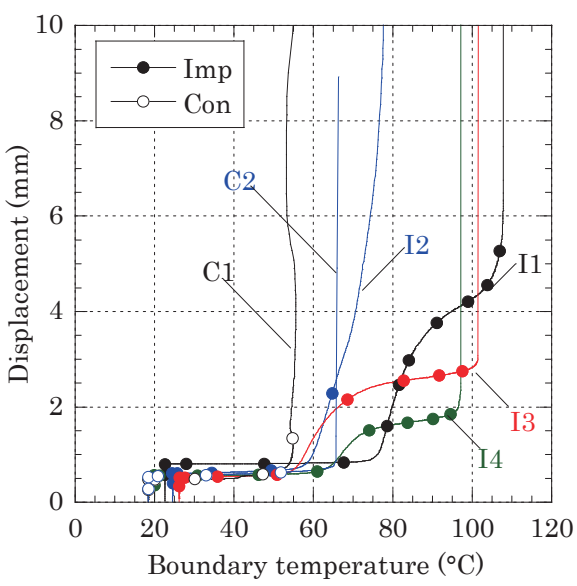

(a) Displacement-boundary temperature

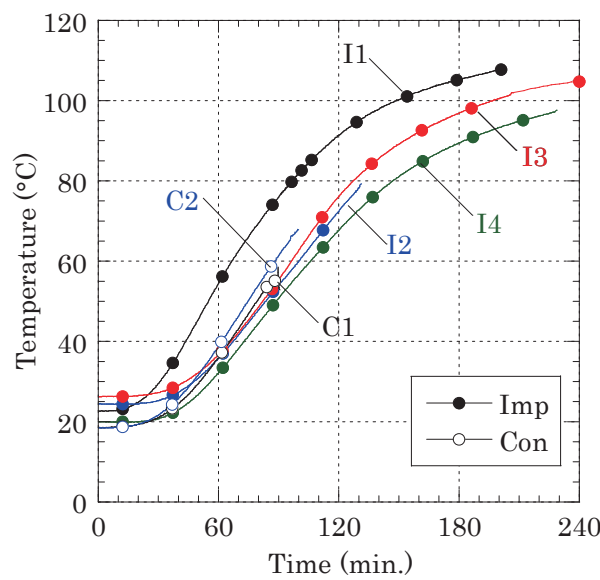

(b) Temperature-time relationship

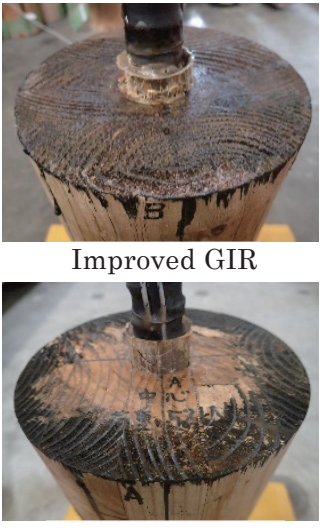

Conventional GIR

(C) Specimens after the experiment

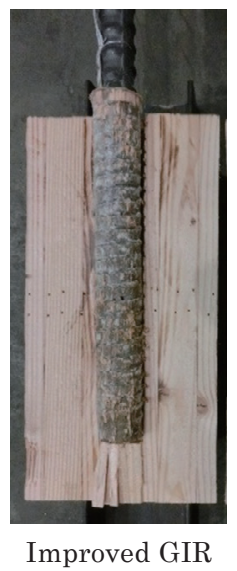

[Note] Imp and I1-I4: Improved GIR; Con and C1-C2: Conventional GIR 


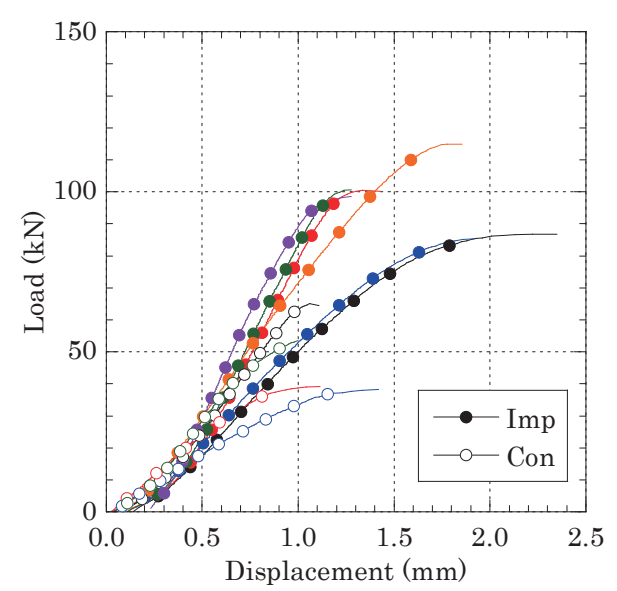

(a) Load-displacement relationship

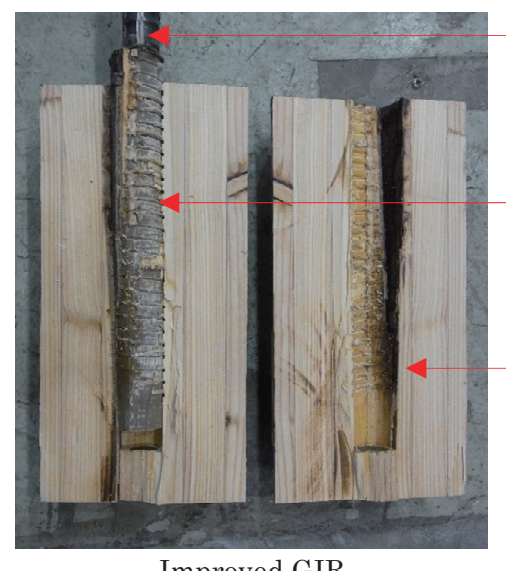

Improved GIR

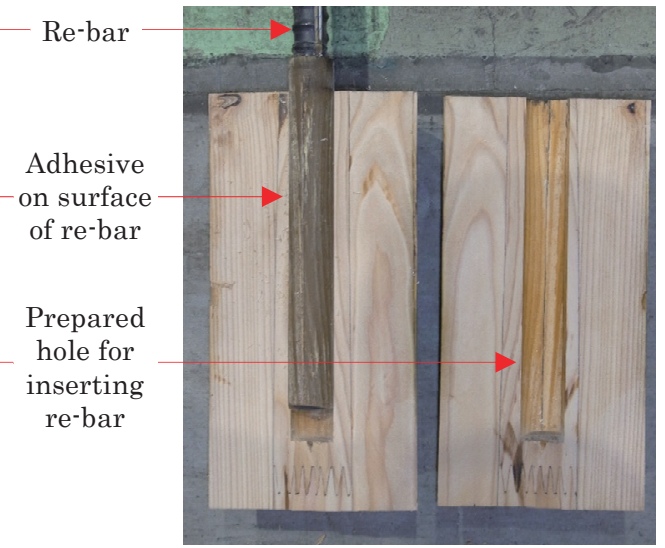

Conventional GIR

(b) Specimens after the experiment

[Note] Imp: Improved GIR; Con: Conventional GIR

Fig. 13 Results of experiment III(NL)

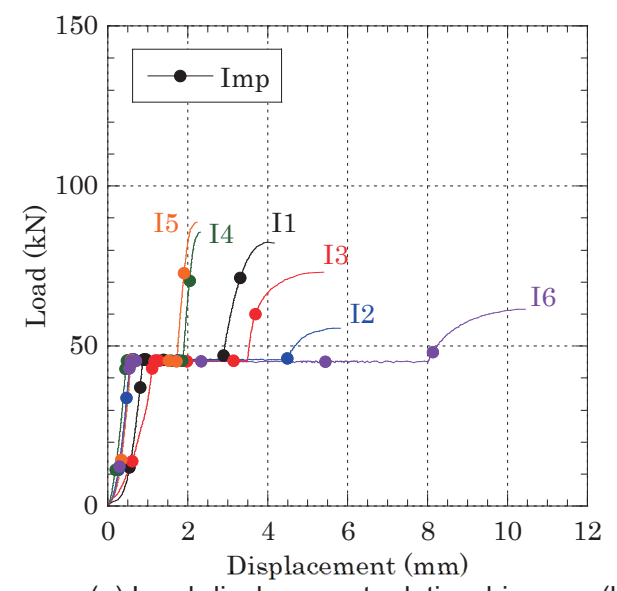

(a) Load-displacement relationship

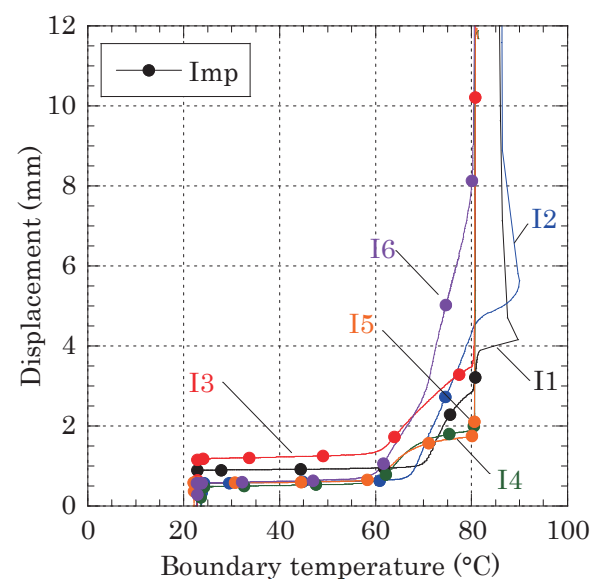

(b) Displacement-boundary temperature relationship

[Note] Imp and I1-I6: Improved GIR

Fig. 14 Results of experiment III(L)

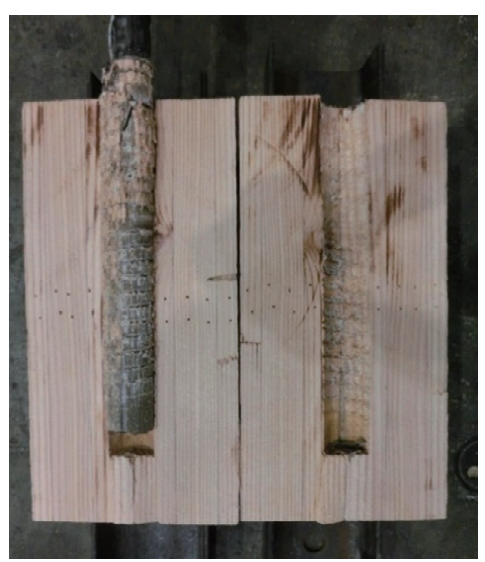

(c) Specimen after the experiment (Improved GIR)

\section{（2）載荷加熱（改 GIR）}

Fig.14 に載荷加熱の場合の荷重一変位関係, 変位一境界温度関係 および引抜実験後の試験体内部の状沉を示す。Fig. 14(a)に示すよう に, 載荷加熱の改 GIR では, $80^{\circ} \mathrm{C}$ に達した時点からの加力による荷 重一変位関係はパラボラ型の曲線形状であった。また, 載荷加熱で あったため, Fig.14(b)に示すように, 昇温過程において鉄筋に引抜

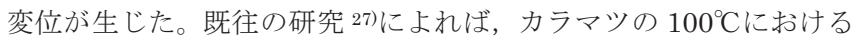
ヤング係数および曲げ強度の常温に対する残存率は, 各々 $0.92,0.75$ になることが報告されており, 引抜強度の低下や引抜変位の増加の 一因として木部の力学的特性の低下が影響していると言える。試験 体間で引抜強度や引抜変位に差が生じた原因としては, 木質材料と いう自然由来の材料であることによるばらつきや, 材料内の水分移 動の影響などの様々な要因が考えられる。昇温過程における引抜変 位が大きいほど高温引抜強度が小さくなる傾向を示した結果の原因 としては, 前述の木質材料のばらつき以外に, $80^{\circ} \mathrm{C}$ 到達時点の残存 付着面積が小さくなっていたことも影響していると考えられる。な お, 図中のI6 はラミナに節が存在していたため, これが影響した可 能性も考えられる。

\section{5 加熱 · 冷却後引抜実験（実験 IV）}

Fig. 15 に荷重一変位関係, 変位一境界温度関係および引抜実験後 の試験体の外観を示す。改 GIR は載荷加熱・冷却, 従来 GIR は無 載荷加熱・冷却である。両者ともに高温引抜実験（実験 III）の結果 に比べると強度・剛性ともに回復し, 非加熱の常温引抜強度と同程 度の引抜強度になっている。改 GIR では，6.4 節(2)で述べたような 木質材料のばらつき等の影響により, 加熱・冷却中の引抜変位量に 試験体による差異が生じた可能性があるものの, 引抜加力時の荷重 一変位関係は概ね同等である。なお, Fig. 15(b)に示されるように, 改 GIR の加熱・冷却中の引抜変位は主に加熱中に生じており, 境界 温度が $55^{\circ} \mathrm{C}$ を超えてからの変位量が大きい。

高温引抜強度と冷却後引抜強度の差異に関して考察すると, 改 GIR と従来 GIR ともに, 高温引抜実験（実験 III）において測定さ れた高温引抜強度よりも冷却後引抜強度の方が高くなっており, こ の要因として, 高温時における既往の研究等 ${ }^{3)-6), 27 に あ る よ う に, ~}$ 木質材料の温度と含水率の影響が考えられる。また, この要因の他 に, 接着剤の強度特性の温度依存性が関係している可能性も考えら れる。しかし, 本研究では接着剤単独の高温時および冷却後の強度 


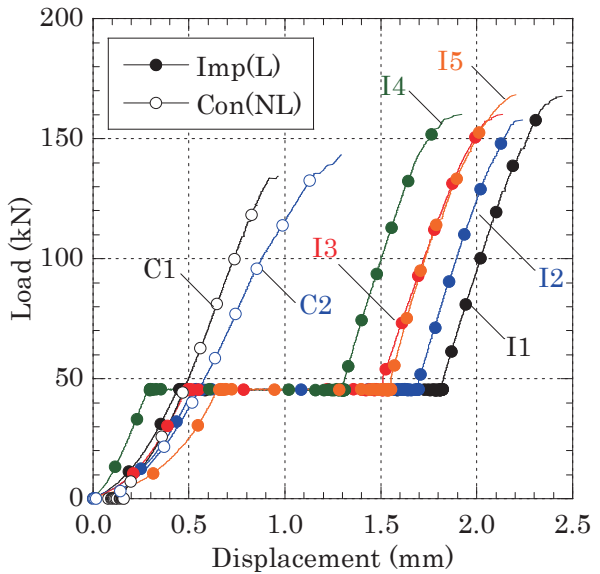

(a) Load-displacement relationship

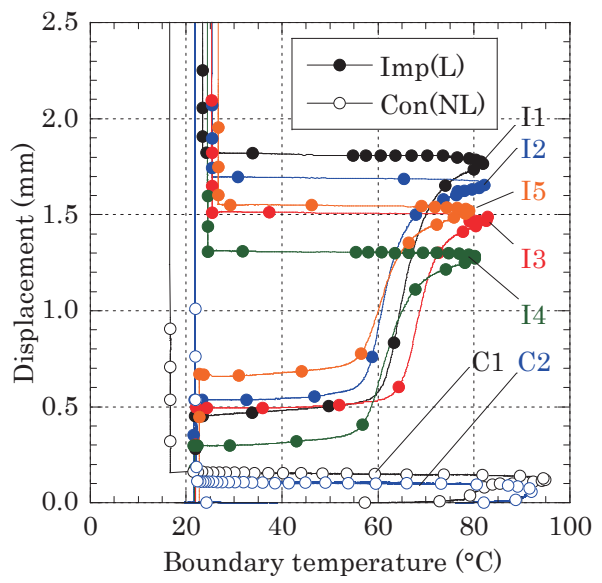

(b) Displacement-boundary temperature relationship
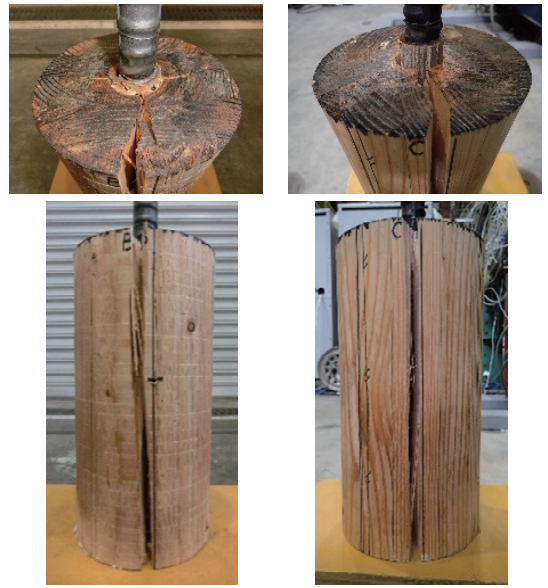

Improved GIR

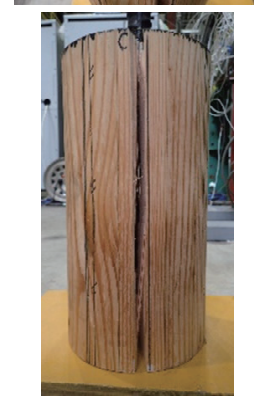

Conventional GIR

(c) Specimens after the experiment

[Note] Imp and I1-I5: Improved GIR; Con and C1-C2: Conventional GIR

Fig. 15 Results of experiment IV

特性を検討していないことから，接着剤の影響等については今後の 検討課題である。

木質材料の温度影響については, 既往の研究 27)によれば, カラマ ツに関して $100^{\circ} \mathrm{C} ら の$ 泠却後におけるヤング係数・曲げ強度の非 加熱に対する残存率がいずれも 1.01 になるという結果が報告され ている。このことから, 境界温度が $80^{\circ} \mathrm{C}$ 程度であれば, 木部の力学 特性は冷却後に回復していると言える。

一方, 木質材料の含水率の影響を調べるため, 改 GIR の試験体に 関して, 引抜実験前および実験後速やかに，水分計（Table 1 脚注 参照）を用いて含水率を測定した。含水率の測定状沉を Photo 3 に 示し, 測定結果を Table 4 亿示す。含水率の測定は, 実験前の試験 体表面（4 箇所），実験後の試験体表面（4 箇所）および内部（表面 側（M1〜M4） 4 箇所，鉄筋側（M5〜M8）4 箇所）で測定し，表に は各実験シリーズにおける全試験体の測定值の平均值を示した。

Table 4 に示すように, 常温引抜実験（実験 I）に供した試験体で は表面と内部の含水率に差異はない。しかし, 一定荷重昇温引抜実 験 (実験 II) および高温引抜実験 (実験 III) の実験後の試験体では, 表面および内部表面側の含水率が $6 \%$ 未満 (測定範囲外), 内部鉄筋 側が 15.6〜 $17.4 \%$ となり, 内部鉄筋側の含水率が常温引抜実験に比 べて高い状態であった。木内部の含有水は加熱に伴って, 加熱表面 から放出される水分と内部へ移動する水分とがあり, 内部一移動し た水分が内部鉄筋側の含水率を増加させたものと言える。実験 II お よび実験 III における力学特性の低下において, この含水率の増加 が影響している可能性も考えられる。これに対して, 加熱・冷却後 引抜実験（実験 IV）の実験後の試験体では, 表面の含水率が $6 \%$ 未 満ではあるものの, 内部表面側が $6.5 \%$, 内部鉄筋側が $11.8 \%$ あっ た。加熱・冷却後引抜実験の試験体では，加熱中に内部鉄筋側に移 動していた水分が泠却期間中に表面側へと移動したため，内部鉄筋 側の含水率が常温引抜実験の試験体とほぼ同等になったものと考え られる。

以上のことから, 加熱・冷却後引抜実験における引抜強度が高温 引抜実験における引抜強度よりも高く, 常温引抜実験における引抜 強度と同程度に回復した一つの要因として, 木部の力学特性の回復

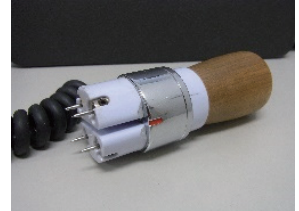

(a) 4-needle probe of wood moisture tester

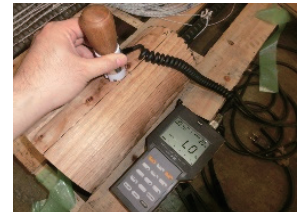

(b) Measuring moisture content on the surface of specimen

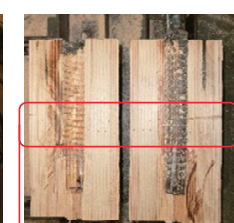

(c) Split cross section of specimen

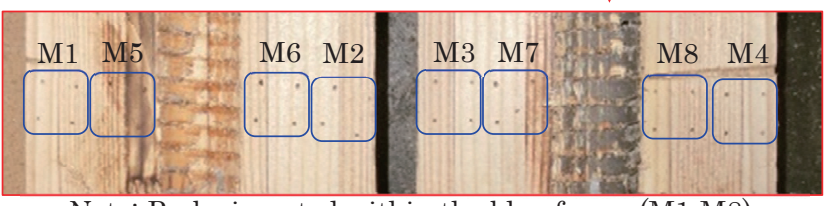

Note: Probe inserted within the blue frame (M1-M8).

(d) Moisture content measurement points inside the specimen

Photo 3 Measurement of moisture content of wood on and inside specimen using wood moisture tester

Table 4 Moisture content of improved GIR specimens before and after pull-out experiments

\begin{tabular}{|c|c|c|c|c|c|}
\hline \multirow{2}{*}{ Experiment } & \multicolumn{4}{|c|}{ Moisture content (\%) *1 } \\
\cline { 2 - 6 } & $\begin{array}{c}\text { Before } \\
\text { expt. }\end{array}$ & \multicolumn{3}{|c|}{ After expt. } \\
\cline { 2 - 6 } & Surface & Surface & $\begin{array}{c}\text { Inside } \\
\text { (M1-M4) } \\
\text { Avg. }\end{array}$ & $\begin{array}{c}\text { Inside } \\
\text { (M5-M8) } \\
\text { Avg. }\end{array}$ \\
\hline \multicolumn{2}{|c|}{ I } & 12.8 & LO & LO & 11.6 \\
\hline \multicolumn{2}{|c|}{ II } & 12.2 & LO & LO & 17.1 \\
\hline \multirow{2}{*}{ III } & NL & 12.3 & LO & LO & 15.6 \\
\cline { 2 - 6 } & L & 12.5 & LO & 6.5 & 11.8 \\
\hline \multicolumn{2}{|c|}{ IV } & 12.2 & &
\end{tabular}

*1 LO: Moisture content is less than $6 \%$.

と内部鉄筇側の含水率が常温引抜実験時の含水率と同程度になって いたことが考えられる。

\section{7. まとめ}

耐熱性エポキシ樹脂系接着剂を用いた GIR 工法の耐熱性の把握 と向上を目的として, 鉄筋を挿入する先孔に溝加工を施していない 従来 GIR 工法および先孔に溝加工を施した改 GIR 工法で製作した 
試験体に対して，常温および高温における引抜実験を実施した。そ の結果，本検討の範囲において，以下の知見が得られた。

- 常温引抜強度（実験 I）：別途行った実験 10)では改 GIR の引抜強 度は従来 GIR と同等以上であったが，本検討における改 GIR の 引抜強度は従来 GIR よりも低く, 従来 GIR の $90 \%$ 程度であった。 このような結果になった原因として, 試験体木部の集成材に関し て, 従来 GIR と改 GIR の製作時期が異なっていたこと, 製作時 にラミナの強度区分やその配置を厳密に管理していなかったこと などの可能性が考えられ, 今後さらなる実験とデータの蓄積が必 要である。

- 一定荷重昇温引抜実験（実験 II）：一定荷重を常温引抜実験の引抜 強度の $1.1 / 3$ としたため, 常温引抜実験と同様にさらなる実験と データの蓄積が必要であるが, 破壊時の平均温度は, 改 GIR が $96^{\circ} \mathrm{C}$, 従来 GIR が $61^{\circ} \mathrm{C}$ であり, 改 GIR の方が $40^{\circ} \mathrm{C}$ 程度高くな った。

・高温引抜実験（実験 III）：引抜強度の平均値は, 改 GIR が無載荷 加熱で $97.7 \mathrm{kN}$, 載荷加熱で $74.5 \mathrm{kN}$ であったのに対し, 従来 GIR は無載荷加熱で $49 \mathrm{kN}$ であった。従来 GIR に比べて改 GIR の方 が無載荷加熱で約 2 倍, 載荷加熱で約 1.5 倍, 引抜強度が高くな った。改 GIR の高温引抜強度は従来 GIR よりも明らかに向上し た。鉄筋を挿入する先孔の内面に施した溝に接着剂が入り込んで 固化することによる機械的な結合が功を奏したものと考えられる。 ・加熱・冷却後引抜実験（実験 IV）：加熱・冷却後の引抜強度は, 改 GIR と従来 GIR の双方で高温引抜強度を大きく上回った。ま た, 非加熱の常温引抜強度と比較しても, 同程度の引抜強度に回 復した。加熱・冷却後の強度回復は, 木部の力学特性の回復とと もに，木部内部の鉄筋側の含水率が，非加熱の木部内部の含水率 と同程度になっていたことが関係しているものと考えられる。ま た, 引抜強度の回復には, 接着剤の強度特性も関係している可能 性があるが，接着剤の影響等については今後の検討課題である。

\section{参考文献}

1) Owa, S. and Ikeda, K.: Experimental Study on Bond Strength of Adhesive Post-Installed Rebars of Epoxy Injection Resin Type During Fire and After Fire, Journal of Structural and Construction Engineering (Transactions of AIJ), Vol.80 No.717, pp.1803-1809, 2015.11 (in Japanese)

大和征良, 池田憲一：エポキシ樹脂系注入方式接着系あと施工アンカー の火災時及び火災後の付着破壊強度に関する実験的研究, 日本建築学会 構造系論文集, 第 80 巻, 第 717 号, pp.1803-1809, 2015.11

2) Thuan, L.T., Owa, S. Song, C. and Ikeda, K.: Experimental Study on Bond Strength of Adhesive Post-Installed Rebar Systems During Fire, Journal of Structural and Construction Engineering (Transactions of AIJ), Vol.84 No.758, pp.575-582, 2019.4

3) Kaku, C., Hasemi, Y., Kamikawa, D., Suzuki, T. Yasui, N., Koshihara, M. and Nagao, H.: Influence of Water Content on the Mechanical Properties of Wood Exposed to Fire - Young's modulus and bending strength of Cryptomeria japonica and Zelkova serrate under various water-containing states at elevated temperature -, Journal of Structural and Construction Engineering (Transactions of AIJ), Vol.82, No.732, pp.299-308, 2017.2 (in Japanese)

加來千紘, 長谷見雄二, 上川大輔, 鈴木達朗, 安井昇, 腰原幹雄, 長尾博 文: 含水率が火災加熱を受ける木材の力学的性能に及ぼす影響一多様な 含水状態におけるスギ及びケヤキの高温時ヤング係数・曲げ強度の測定 一, 日本建築学会構造系論文集, 第 82 巻, 第 732 号, pp.299-308, 2017.2

4) Kaku, C., Hasemi, Y., Kamikawa, D., Suzuki, T. Yasui, N., Koshihara,
M. and Nagao, H.: Corrigenda: Influence of Water Content on the Mechanical Properties of Wood Exposed to Fire - Young's modulus and bending strength of Cryptomeria japonica and Zelkova serrate under various water-containing states at elevated temperature -, Journal of Structural and Construction Engineering (Transactions of AIJ), Vol.85, No.769, pp.451-453, 2020.3 (in Japanese)

加來千紘, 長谷見雄二, 上川大輔, 鈴木達朗, 安井昇, 腰原幹雄, 長尾博 文 : 訂正 : 含水率が火災加熱を受ける木材の力学的性能に及ぼす影響一 多様な含水状態におけるスギ及びケヤキの高温時ヤング係数・曲げ強度 の測定一, 日本建築学会構造系論文集, 第 85 巻, 第 769 号, pp.451-453, 2020.3

5) Architectural Institute of Japan: Outline of Guide Book for FireResistive Performance of Structural Materials (Third edition), 2017 (in Japanese)

日本建築学会 : 構造材料の耐火性ガイドブック（第 3 版）, 2017

6) Watanabe, S., Suzuki, T., Hasemi, Y., Kaku, C., Kamikawa, D., Yasui, N. and Miyamoto, K.: Dependence of the Mechanical Properties of Wood on Temperature, Moisture Content and Tree Species at Elevated Temperatures - Measurement of Young's modulus and bending strength on major structural tree species and examination of the predictability of the mechanical properties at elevated temperatures based on material properties -, Journal of Structural and Construction Engineering (Transactions of AIJ), Vol.84, No.761, pp.1011-1020, 2019.7 (in Japanese)

渡辺秀太, 鈴木達朗, 長谷見雄二, 加來千紘, 上川大輔, 安井昇, 宮本康 太 : 多様な樹種の木材の力学的性能に対寸る温度・含水率の影響の把握 と予測可能性 - 構造用主要樹種に関するデータ構築と全乾密度に基づ <予測可能性の検討 -, 日本建築学会構造系論文集, 第 84 巻, 第 761 号, pp.1011-1020, 2019.7

7) Ministry of Land, Infrastructure and Transport, Housing Bureau, Building Guidance Division et al.: Explanation and Calculation Example of Fireproof Performance Verification Method (2001 version), 2001.3 (in Japanese)

国土交通省 住宅局 建築指導課 他 : 2001 年版 耐火性能検証法の解説 及び計算例, 2001.3

8) Morita, T., Tsubata, S., Nishiya, T., Yamanobe, K., Wada, M. and Okuyama, T.: Development of Structural Joint for Realization of Large Space Timber Structure - Part.1 Outline of heat resistance experiment and experimental method -, Summaries of Technical Papers of Annual Meeting, Architectural Institute of Japan, Structure III, pp.379-380, 2018.7 (in Japanese)

森田武, 津畑慎哉, 西谷隆之, 山野辺宏治, 和田真美, 奥山孝之: 木質構 造による大空間の実現に向けた木アーチ継手の開発一その 1 . 耐熱要素 実験の概要と実験方法一, 日本建築学会大会学術講演梗概集, 構造 III, pp.379-380, 2018.7

9) Okuyama, T., Morita, T., Tsubata, S., Nishiya, T., Yamanobe, K., and Wada, M.: Development of Structural Joint for Realization of Large Space Timber Structure - Part.2 Results of heat resistance experiment -, Summaries of Technical Papers of Annual Meeting, Architectural Institute of Japan, Structure III, pp.381-382, 2018.7 (in Japanese) 奥山孝之, 森田武, 津畑慎哉, 西谷隆之, 山野辺宏治, 和田真美 : 木質構 造による大空間の実現に向けた木アーチ継手の開発一その 2. 耐熱要素 実験の結果一, 日本建築学会大会学術講演梗概集, 構造III, pp.381-382, 2018.7

10) Wada, M., Tsubata, S., Nishiya, T., Yamanobe, K., and Morita, T.: Development of Structural Joint for Realization of Large Space Timber Structure - Part.3 Structural element test -, Summaries of Technical Papers of Annual Meeting, Architectural Institute of Japan, Structure III, pp.383-384, 2018.7 (in Japanese)

和田真美, 津畑慎哉, 西谷隆之, 山野辺宏治, 森田武 : 木質構造による大 空間の実現に向けた木アーチ継手の開発一その 3. 構造要素実験一, 日本 建築学会大会学術講演梗概集, 構造III, pp.383-384, 2018.7

11) Tsubata, S., Nishiya, T., Wada, M., Yamanobe, K., and Morita, T.: Development of Structural Joint for Realization of Large Space Timber Structure - Part.4 Bending experiment of joint -, Summaries of Technical Papers of Annual Meeting, Architectural Institute of Japan, 
Structure III, pp.385-386, 2018.7 (in Japanese)

津畑慎哉, 西谷隆之, 和田真美, 山野辺宏治, 森田武: 木質構造による大 空間の実現に向けた木アーチ継手の開発一その 4 . 大断面継手の実大曲 げ実験一, 日本建築学会大会学術講演梗概集, 構造 III, pp.385-386, 2018.7

12) Wakamatsu, T.: Study on Calculation of Internal Temperature of Building Members in Case of Fire (1st report) -Derivation of calculation formula, calculation conditions and calculation factors-, Transactions of the Architectural Institute of Japan, No.109, pp.73-79, 1965.3 (in Japanese)

若松孝旺：火災時における建物部材の内部温度算定に関する研究（第一 報）一算定式の誘導, 算定条件および算定要素一, 日本建築学会論文報告 集, 第 109 号, pp.73-79, 1965.3

13) Wakamatsu, T.: Study on Calculation of Internal Temperature of Building Members in Fire (2nd Report) -Solution of calculation formula-, Transactions of the Architectural Institute of Japan, No.111, pp.31-36, 1965.5 (in Japanese)

若松孝旺：火災時における建物部材の内部温度算定に関する研究（第二 報）一算定式の解法一, 日本建築学会論文報告集, 第 111 号, pp.31-36, 1965.5

14) Morita, T., Wakamatsu, T., Uesugi, H. and Saito, H.: Analyses of Composite Beams and Frames at Elevated Temperature, Fire Safety Science - Proceedings of the Third International Symposium on Fire Safety Science, pp.761-770, 1991

15) Harada, K., Kajiyama, K., Yusa, S., Uesugi, S. and Namiki, Y.: Numerical Analysis of Charring Behavior of Wood-based Constructions, 2004 Architectural Institute of Japan Kinki Chapter Research Reports (Environmental), pp.209-212, 2004 (in Japanese) 原田和典, 梶山幸祐, 遊佐秀逸, 上杉三郎, 並木勝義 : 木質構造部材の炭 化性状に関寸る数值解析, 平成 16 年度日本建築学会近畿支部研究報告集 (環境系) , pp.209-212, 2004

16) Ito, K., Jiang, X., Tanaka, K., Lee, W., Song, C., Koshihara, M. and Inoue, M.: Fundamental Study for Structural Design of Multi-Stories Large-Scale Timber Building - Pull-out test of glued-in rod joint from LVL -, Architectural Institute of Japan Kyushu Chapter Research Reports, Vol. 52, pp.701-704, 2013.3 (in Japanese)

伊東和俊, 姜暁光, 宗昌錫, 李元羽, 田中圭, 腰原幹雄, 井上正文: 中層大 規模木造の構造設計のための基礎的研究－LVL を母材とした GIR 接合 の引抜き実験, 日本建築学会九州支部研究報告 第 52 号, pp.701-704, 2013.3

17) Inoue, M., Ito, K., Jiang, X., Song, C., Lee, W., Tanaka, K. and Koshihara, M.: Pull-Out Test of Glued-in Rod Joint from LVL, Summaries of Technical Papers of Annual Meeting, Architectural Institute of Japan, Structure III, pp.29-30, 2013.7 (in Japanese) 井上正文, 伊藤和俊, 姜暁光, 宗昌錫, 李元羽, 田中圭, 腰原幹雄 : LVL に挿入されたグルードインロッド接合の引抜実験, 日本建築学会大会学 術講演梗概集, 構造III, pp.29-30, 2013.7

18) Nooguchi, Y., Jiang, X., Kambe, W., Tanaka, K., Mori, T. and Inoue, M.: Estimation Method for Splitting Strength of Glued-in Rod Joint Inserted into Perpendicular to the Grain Part.1 A proposal of estimation method using fracture toughness by compact tension tests, Summaries of Technical Papers of Annual Meeting, Architectural Institute of Japan, Structure III, pp.563-564, 2012.7 (in Japanese) 野口雄司, 姜暁光, 神戸渡, 田中圭, 森拓郎, 井上正文 : 繊維直交方向に 挿入した GIR 接合部の割裂耐力推定法（その 1) コンパクトテンション 試験による破壊靸性値を用いた推定法の提案, 日本建築学会大会学術講 演梗概集，構造III, pp.563-564, 2012.7

19) Nasu, H., Choi, H., Katabami, M. and Noguchi, H.: Studies on the Cross Laminated Timber Joint System Using Large Diameter Screw Bolts Part.1 Experiment purpose and summary, Summaries of Technical Papers of Annual Meeting, Architectural Institute of Japan, Structure III, pp.571-572, 2012.7 (in Japanese)

那須秀行，チェヒョンチョル，方波見雅彦，野口弘行：大径ボルトを用い た CLT 接合部に関する研究（その 1) 実験目的・概要，日本建築学会大 会学術講演梗概集, 構造III, pp.571-572, 2012.7

20) Nakatani, M., Mori, T., Nakashima, S. and Shibata, A.: Pull-Out
Properties of Lag Screw Bolt Embedded in CLT Perpendicular to the Laminated Direction, Summaries of Technical Papers of Annual Meeting, Architectural Institute of Japan, Structure III, pp.27-28, 2013.7 (in Japanese)

中谷誠, 森拓郎, 中島晶一, 椎葉淳: CLT のラミナ積層方向と直交方向の LSB の引抜性能, 日本建築学会大会学術講演梗概集, 構造III, pp.27-28, 2013.7

21) Tanaka, K., Noguchi, Y., Kanbe, W., Mori, T. and Inoue, M.: A Proposal of Estimating Method for Splitting Strength of Glued-In Rod Joint Inserted into Perpendicular to the Grain Glulam, Journal of Structural Engineering, Vol.58B, pp.265-270, 2012.3 (in Japanese) 田中圭, 野口雄司, 神戸渡, 森拓郎, 井上正文 : 集成材の繊維直交方向に 挿入した GIR 接合部の割裂耐力推定法の提案, 構造工学論文集, Vol.58B, pp.265-270, 2012.3

22) Japan Society of Civil Engineers: JSCE-G 503-2010 Method of Test for Bond Strength between Concrete and Reinforcing Steel Bar (Draft), Standard specifications for concrete structures: test methods and specifications - JSCE standards -, 2010 (in Japanese)

土木学会: JSCE-G 503-2010 引抜き試験による鉄筋とコンクリートの付 着強度試験方法(案), コンクリート標準示方書 2010 年制定〔規準編〕

23) Murata, J.: Method of Test for Bond Strength Between Concrete and Reinforcing Steel Bar, Concrete Journal, Vol.18, No.4, pp.14-22, 1980.4 (in Japanese)

村田二郎：引抜き試験による鉄筋とコンクリートとの付着強度試験方法 (案)，コンクリート工学, Vol.18, No.4, pp.14-22, 1980.4

24) Japanese Industrial Standards Committee: JIS A 2101 Methods of Test for Woods, 2009 (in Japanese)

日本産業調查会：JIS Z 2101 木材の試験方法, 2009

25) Architectural Institute of Japan: Standard for Structural Design of Timber Structures (Fourth edition), 2006 (in Japanese) 日本建築学会 : 木質構造設計規準 - 同解説一許容応力度 - 許容而力設計 法一（第 4 版）, 2006

26) Hirota, M., Morita, T., Ido, K., Endo, T., Mizuochi, H. and Sadahiro, O.: Performance Confirmation and Application of Fire-Resistant Wood Members and Hybrid Wood Joint Incorporating Heat-Foaming Material, AIJ Journal of Technology and Design. Vol.27, No.65, pp.265-270, 2021.2 (in Japanese)

広田正之, 森田武, 井戸和彦, 遠藤智紀, 水落秀木, 貞広修 : 加熱発泡材 を組み込んだ耐火木質部材・接合部の性能確認と適用，日本建築学会技 術報告集, 第 27 巻, 第 65 号, pp.265-270, 2021.2

27) Kaku, C., Hasemi, Y., Yasui, N., Yasukawa, M., Kamikawa, D., Kameyama, N., Ono, T., Koshihara, M. and Nagao, H.: Influence of Fire Exposure on the Mechanical Prpoerties of Wood - Exposure temperature dependence of Young's modulus and bending strength of Cryptomeria japonica, Larix leptolepis, Pseudotsuga menziesii and Zelkova serrata under and after heating -, Journal of Structural and Construction Engineering (Transactions of AIJ), Vol. 79 No. 701, pp.1065-1072, 2014.7 (in Japanese)

加來千紘, 長谷見雄二, 安井昇, 保川みずほ, 上川大輔, 亀山直央, 小野 徹郎, 腰原幹雄, 長尾博文: 火災加熱が木材の力学的性能に及ぼす影響一 加熱した針葉樹材及び広葉樹材の高温時及び加熱冷却後のヤング係数・ 曲げ強度の測定一, 日本建築学会構造系論文集, 第 79 巻, 第 701 号, pp.1065-1072, 2014.7 


\title{
EXPERIMENTAL STUDY TO IMPROVE THE THERMAL MECHANICAL PROPERTIES OF GLUED-IN ROD JOINTS FOR WOODEN STRUCTURAL MEMBERS
}

\author{
TakeshiMORITA ${ }^{* 1}$,Shinya TSUBATA ${ }^{* 2}$, Takayuki NISHIYA *3 \\ and Koji YAMANOBE*4 \\ ${ }^{*}$ Group Manager, Institute of Technology, Shimizu Corporation, Dr.Eng. \\ *2 Research Engineer, Institute of Technology, Shimizu Corporation, M.Eng. \\ ${ }^{*}$ Chief Design Manager, Design Division, Shimizu Corporation, M.Eng. \\ ${ }^{*}$ Chief Research Engineer, Institute of Technology, Shimizu Corporation, Dr.Eng.
}

The purpose of this experimental study was to understand and improve the heat resistance of the glued-in rod (GIR) method of joining wooden members. Experiments were carried out with the conventional GIR method (Con), in which the inner surface of the reinforcing bar insertion hole is smooth, and an improved GIR method (Imp), in which the inner surface of the insertion hole is grooved with the expectation of improved mechanical bond strength.

The experimental procedure can be broadly divided into three steps, as follows.

Step 1: Assuming a building containing wooden members jointed using the GIR method, the internal temperature of a GIR joint in the event of a building fire was calculated by unsteady heat transfer analysis. This temperature, $80^{\circ} \mathrm{C}$, was then set as the target temperature for pull-out experiments.

Step 2: The heating required to achieve the target $80^{\circ} \mathrm{C}$ boundary temperature between adhesive and wood in the GIR joint specimen was determined and experimentally verified by analytically examining the temperature-time relationship. It was determined that the temperature in the electric furnace used to heat the specimen should be raised to $180^{\circ} \mathrm{C}$ over a period of 35 minutes.

Step 3: Based on the determinations made in steps 1 and 2, the following pull-out experiments were carried out:

- Experiment I: Pull-out from unheated specimens at room temperature.

- Experiment II: Pull-out under constant load from specimens during heating.

- Experiment III: Pull-out from specimens when the boundary temperature reaches the target of $80^{\circ} \mathrm{C}$. The loaded or unloaded state during heating was a parameter in these pull-out experiments.

- Experiment IV: Pull-out from specimens after initially raising the boundary temperature to $80^{\circ} \mathrm{C}$, holding it there for about 2 to 3 hours, and cooling again.

The results obtained from these various pull-out experiments were as follows.

- Experiment I: The pull-out strength of Imp was lower (about 90\%) than that of Con. The cause of this has not been clarified, and further experiments and data accumulation will be required in the future.

- Experiment II: The boundary temperature at the time of pull-out failure was $96^{\circ} \mathrm{C}$ for $\operatorname{Imp}$ and $61^{\circ} \mathrm{C}$ for Con. The loading in this experiment was fixed at $37 \%$ of the room temperature pull-out strength, so further experiments and data accumulation will be required for other loadings.

- Experiment III: The average pull-out strength of Imp was $97.7 \mathrm{kN}$ for unloaded heating (49 kN for Con) and $74.5 \mathrm{kN}$ for loaded heating. Thus the pull-out strength of Imp under unloaded heating was about twice as high as that of Con. The pull-out strength of Imp under loaded heating was about 1.5 times as high as the pull-out strength of Con under unloaded heating. The high-temperature pull-out strength of Imp is clearly an improvement over that of Con.

- Experiment IV: The pull-out strength after heating and cooling greatly exceeded the high-temperature pull-out strength in both Imp and Con, and was almost equal to the unheated room-temperature pull-out strength. One of the reasons for the exhibited strength recovery may be that the moisture content near the boundary between adhesive and wood after heating and cooling was almost the same as that of the unheated wood.

(2021 年 2 月 6 日原稿受理, 2021 年 8 月 2 日採用決定 